\title{
Design and Build: What Does Realisation of a Student Design Bring into Architectural Education?
}

\section{Navrhni a postav: Co prinináši do výuky architektury realizace studentského návrhu?}

\author{
Šárka Malošíková \\ 15128 Ústav navrhování II, Fakulta architektury, České vysoké učení technické v Praze \\ školitel: Ing. arch. Dalibor Hlaváček, Ph.D.
}

\begin{abstract}
Design-build projects represent a teaching method of architectural design, during which students are enabled to develop their design up to construction phase. Examples of this method are found at many schools of architecture. However, the project scope, form, and aims often vary. This paper discusses main themes of design-build project pedagogy during the last century, focuses on benefits and limits of this method, indicate possible overlap toward research or opportunity of closer cooperation between a school of architecture and a community or a real client, and embeds it in a unifying wider theoretical framework
\end{abstract}

KEYWORDS: design-build; tacit knowledge; architectural education

\begin{abstract}
ABSTRAKT: Design-build projekty představují způsob výuky architektonického navrhování, při kterém studenti své návrhy dovádí až $\mathrm{k}$ realizaci. Př́́klady tohoto př́istupu najdeme na mnoha školách architektury. Rozsah, forma a cíle projektů se ale často liší. Příspěvek se zabývá hlavními tématy výuky design-build projektů v průběhu posledního století, zaměřje se na př́nosy a omezení tohoto prrístupu, naznačuje př́padný přesah do výzkumné činnosti nebo možnosti užší spolupráce školy architektury s komunitou či skutečným klientem a zasazuje jej do sjednocujícího širšího teoretického rámce.
\end{abstract}

KLÍČOVÁ SLOVA: design-build; tacitní znalosti; architektonické vzdělávání 


\section{Úvod}

V několika posledních desetiletích se na školách architektury rozvíjí výuka tzv. design-build projektů, tedy takových studentských projektů, které umožňují vlastní návrh rozvíjet až do fáze výstavby. Tato alternativa ke standardnímu způsobu výuky ateliéru přibližuje akademické prostředí architektonické praxi, a to nejen díky reálnému zadání, ale především díky šiři úkolů a rolí, se kterými se studenti architektury $\mathrm{v}$ průběhu práce setkávají. Na rozdíl od praxe navíc studenti stavějí svůj návrh vlastníma rukama a díky tomu mají možnost se úzce seznámit s vybranými materiály, postupy výstavby, prováděním detailů, a především utvářením prostoru.

Podoba design-build projektů vyučovaných na různých školách architektury se velmi liší. Převážná část zahraniční odborné literatury věnuje pozornost především podmínkám vzniku, průběhu a dokončení jednotlivých projektů a jejich analýze. Design-build projekty jsou posuzovány podle řady kategorií (Anderson, Priest, 2014; Fattinger, 2014). Jejich podobu také podstatně určuje osobnost pedagoga a jím zvolený způsob výuky. Tento aspekt zohledňuje ve své definici William Carpenter: „Design-build (př́stup) je v architektonickém vzdělávání definován jako vzájemný vztah mezi konceptuálními myšlenkami a realizací projektu. Během tohoto procesu se myšlenky vynořují v prủběhu výstavby. Design-build probíhá někdy jako týmová práce anebo jako individuální zkoumání v závislosti na vedoucím a jeho zájmech v rámci projektu a učebních cílù." (Carpenter, 2004, s. 11)

Poslední dobou přibývá mezi zainteresovanou odbornou veřejností hlasů, které volají po zasazení této metody do širšího teoretického rámce (Verderber, 2014; Morrow, 2014, s. xxi). Př́spěvek se proto zaměřuje na vývoj tohoto zpo̊sobu výuky v posledních zhruba sto letech a propojuje jej se soudobými náhledy na získávání poznání skrze vlastní zkušenost. Text vychází z rešerší design-build projektů a ze studia odborné literatury

\section{Design-build projekty v historii architektonického vzdělávání}

Výuka design-build projektů se $\mathrm{v}$ principu vrací zpět $\mathrm{k}$ původní roli architekta - hlavního stavitele. Jak uvádí Bernard Tschumi (1995, s. 24), „od dob pyramid až po středověk žil architekt na staveništi a jen zř́dka pracoval jako nezávislý odborník". Během následujících staletí se však architektura od samotného stavění stále vzdalovala. Nejvýznamnější odklon znamenal vznik vlivné Académie royale d'architecture a její následnice Académie des beaux-arts, které se zaměřovaly na reprezentativní aspekty architektury a hledání ideální proporce založené na pravidlech klasické antické architektury (Kostof, 1997). 
Nejvýznamnější pokus o vědomé zvrácení této tendence na počátku 20. století přinesla německá avantgardní škola Bauhaus založená Walterem Gropiem. Na narůstající rozdíl mezi akademickým vzděláním a praktickými požadavky praxe ovlivňované všudypř́tomnou industrializací Gropius reagoval navrácením se k tradici středověkého vzdělávání řemeslníků. Po splnění úvodního kurzu (obr. 1), který trval šest měsíců, si mohli studenti vybrat jednu z uměleckých dílen. $\mathrm{V}$ jejím čele stál umělec, tzv. „mistr formy“, jemuž asistoval v daném oboru praktikující „mistr řemesla“. Kvůli nedostatku financí $\mathrm{v}$ začátcích Bauhausu studenti během výuky pracovali i na některých Gropiových stavbách (Grave a Wick, 2011, s. 46).

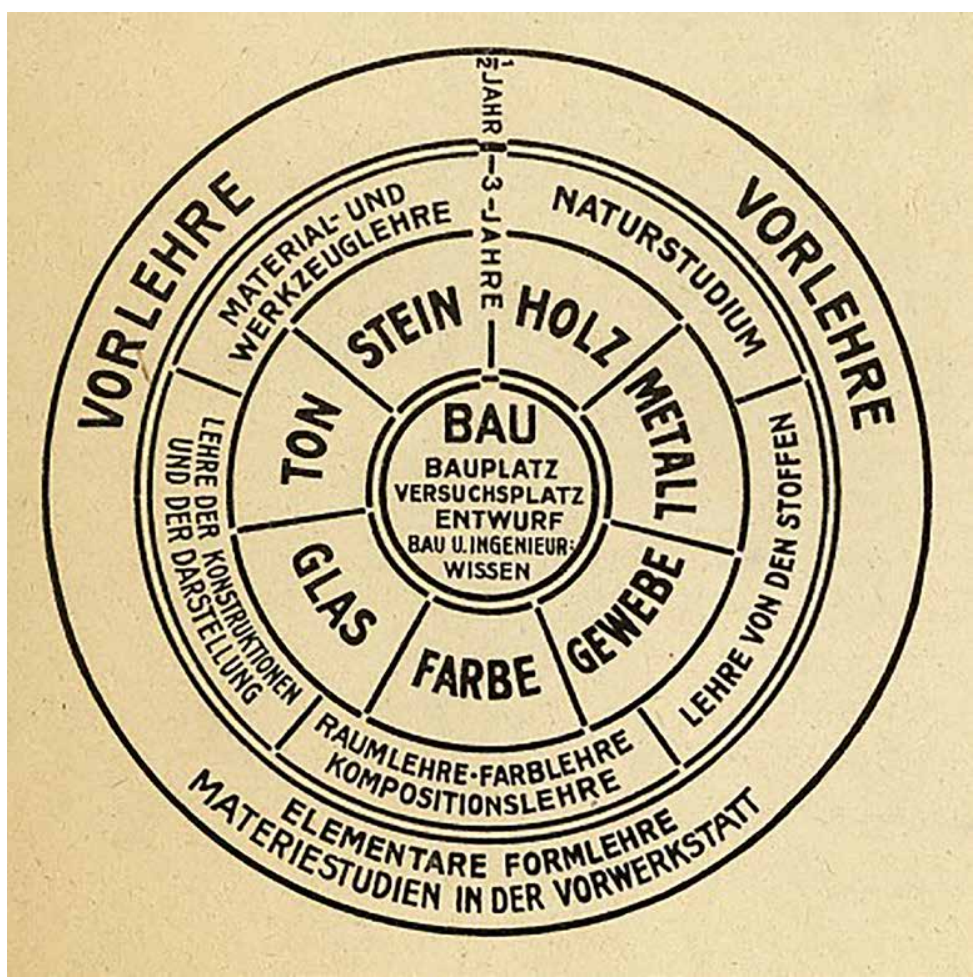

Obr. 1. Schéma výuky na škole Bauhaus (Zdroj: https://www.bauhaus.de/en/das_ bauhaus/45_unterricht/ [cit. 2018-08-30])

Jako další př́iklad raných design-build projektů lze uvést vzdělávání architektonických učňů pod vedením Franka Lloyda Wrighta, který je zapojoval do stavby sídla školy v Taliesinu (obr. 2) i dalších svých projektů. Wrightův prŕístup byl silně ovlivněn jeho dvěma tetami, které založily soukromou školu pro děti, na níž se vyučovalo podle hesla „learning by doing“ (The School of Architecture at Taliesin, 2018). Vychá- 
zel z aktuálních myšlenek pragmatické pedagogiky a jejího hlavního představitele, předního amerického filosofa a reformátora vzdělávání Johna Deweyho [1]. Stejným hnutím byla ovlivněna i škola Black Mountains College, založená v roce 1933, jež měla velmi úzké vazby na bývalé učitele Bauhausu, kteří po nástupu nacismu emigrovali do Spojených států. I zde se studenti podíleli na stavbě nové budovy školy. V poválečných letech na Black Mountains College učil i Buckminster Fuller experimentující při výuce s „mock-upy“ geodesických struktur.

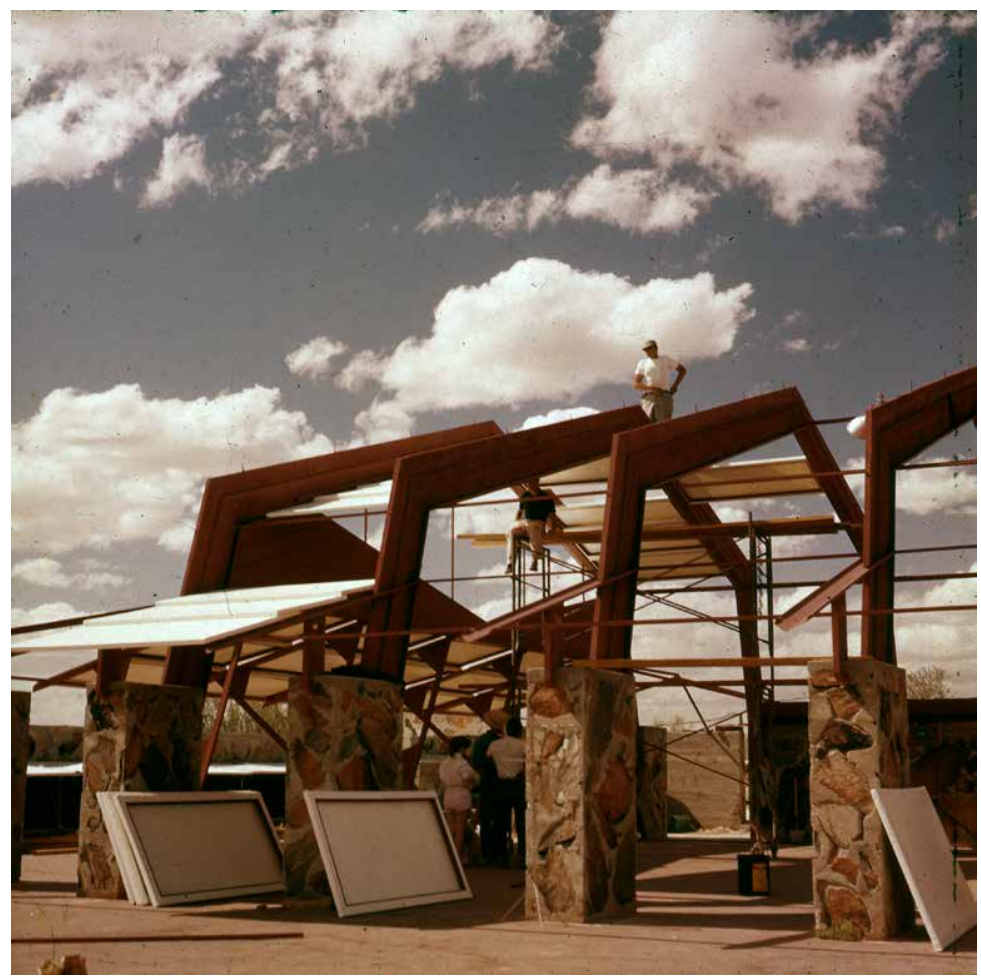

Obr. 2. Stavba hudebního pavilonu v Taliesin West, 1952, fotograf John Amarantides (Zdroj: Copyright $\odot$ Frank Lloyd Wright Foundation, Scottsdale, AZ. All rights reserved)

O design-build projektech zasazených do oficiálního univerzitního prostředí ale můžeme hovořit až v prŕpadě výuky na Katedře architektury Yaleovy univerzity v 60. letech za vedení Charlese W. Moora, kde vzniklo z podnětu studentů ovlivněných soudobou atmosférou ve společnosti několik komunitních center. Postupným vývojem se na této škole staly design-build projekty pevnou součástí výuky prvního ročníku, v jejímž rámci studenti během jednoho roku navrhnou a postaví ve spolupráci s neziskovým sektorem jeden zpravidla dvoupodlažní rodinný dům (Hayes, 2007). 


\section{Současné tendence}

Následný vývoj výuky design-build lze stručně popsat jen s velkou mírou zjednodušení. Ve Spojených státech se touto výukou začala zabývat celá řada ateliérů, mezi nejznámějšími alabamské Rural Studio nebo uskupení Jersey Devil. Dnes jsou design-build projekty zastoupeny v osnovách většiny amerických škol (Gregory, 2014). Kromě zkušenosti se stavbou a s různými aspekty práce architekta je zde důležitým tématem spolupráce s místní komunitou, která by si jinak zapojení architekta nemohla dovolit. V posledních letech se $\mathrm{v}$ tomto smyslu zájem přesouvá i do rozvojových zemí, kde vznikají školy, nemocnice či komunitní centra. Dalším tématem je např́iklad udržitelnost a uplatnění nových technologiía poznatků voblasti nakládání s energiemi. V Evropě se výuka design-build projektů začala výrazněji prosazovat po roce 2000 . V posledních letech je možné zaznamenat vznik programů, jež celé své kurikulum přizpůsobují design-build prrístupu. Př́ikladem je magisterský program London AA nazvaný Design + Make, založený v roce 2010, jehož hlavním zaměřením je inovativní návrh. Studenti architektury zde během dvou let společně navrhnou a postaví objekt s použitím nejnovějších technologií (obr. 3) a následně o něm napíší individuální teoretickou práci. Nechybí zde tedy ani následná reflexe a propojení s výzkumem zaměřeným na architektonické navrhování.

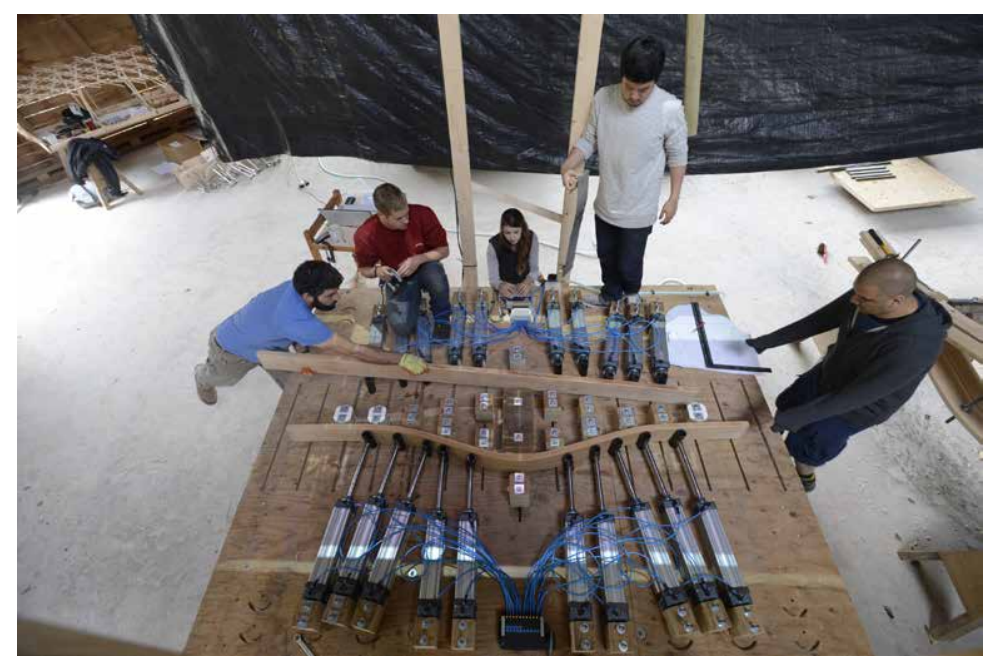

Obr. 3. Upínák na ohýbání individuálně tvarovaných dřevěných lamel, projekt venkovního prŕístřešku na dřevo, program Design + Make, London AA, 2014 (Zdroj: Architectural Association Photo Library) 
Ne vždy je ale výsledkem semestrální práce budova. Jedním z důvodů může být zdlouhavost povolovacího procesu, která neumožňuje dokončit navrhovaný projekt $\mathrm{v}$ rámci jednoho semestru či akademického roku. Studenti se tedy zabývají jednoduššími typy objektů, jako jsou např́klad altány, mobiliář či experimentální struktury (obr. 4).

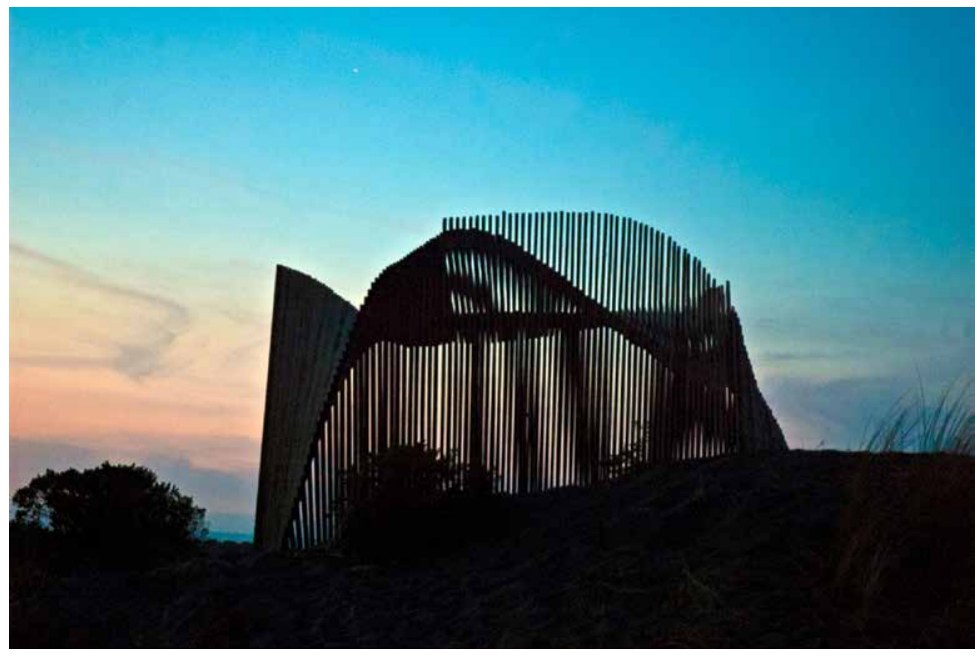

Obr. 4. Hospederia de las Alas, úkryt pro pozorování ptáků, Chile, ateliér Scarcity and Creativity, 2012 (Zdroj: Scarcity and Creativity)

Alberto Pérez-Gómez k této pestrosti přístupů v úvodním slově ke knize Designbuild Education píše: „Bez ohledu na takto rozdílné záměry sdílejí design-build př́stupy rozhodující přesvědčení, že je pro tvưrči profesi di̊ležité vtělené poznání." (Kraus, 2017, s. xiii) Gómez tak vsazuje design-build projekty do fenomenologického rámce vnímání světa skrze vlastní zkušenost, která vede k rozvoji intuice. Vlastní konstruování poznání umožňuje vznik tzv. tacitních znalostí, které jsou slovy nepředatelné. Postupným získáváním zkušeností nabývají budoucí architekti schopnosti umožňující snadnější komunikaci s odborníky tak, jak to popisuje Juhani Pallasmaa na príkladu spolupráce Tapia Wirkkaly a benátské firmy Venini, při níž „sdílená znalost materiálu, sdílená ambice podat výkon na hranici možností řemesla a osobní dovednosti spolu s logikou samotné práce nabídly syntax pro tichý jazyk..."(Pallasmaa, 2012, s. 62). Tacitní znalosti získáváme implicitně a jejich získávání je tedy možné ověřit jen nepř́mo (Švec et al., 2016). Proto je třeba dalšího výzkumu, který by byl schopen ozřejmit jejich roli v design-build výuce a prrinést tak poznatky, které by mohly vést nejen $\mathrm{k}$ zefektivnění této metody, ale i k celkové změně nahlížení na roli přímé zkušenosti $\mathrm{v}$ architektonickém vzdělávání. 


\section{Závěr}

Výuka prostřednictvím design-build projektů představuje v architektonickém vzdělávání jednu $\mathrm{z}$ alternativ $\mathrm{k}$ tradičnímu způsobu výuky, která má své kořeny již na počátku dvacátého století. Postihnout celou šiři přístupů a vnějších i vnitřních faktorů ovlivňujících její kvalitu je díky narůstajícímu počtu příkladů obtížné. Přesto lze říci, že jejím hlavním posláním je nabídnout studentům již v raných fázích studia možnost zrealizovat vlastní návrh a díky tomu se setkat $s$ dalšími aspekty práce architekta. Především umožňuje plně rozvinout schopnost komunikace a mentální konstrukce návrhu ještě předtím, než je postaven. Kromě explicitních znalostí tak přináší i znalosti tacitní, které jsou pro kvalitní práci architekta nepostradatelné, přesto jen velmi těžko předatelné $\mathrm{v}$ rámci výuky. Proto je třeba jim věnovat pozornost v dalším výzkumu.

Př́íspěvek byl podpořen z prostředků grantu SGS17/145/OHK1/2T/15 - Live Projects ve výuce architektury.

\section{Poznámky}

[1] Myšlenky Johna Deweyho a jeho následovníků se dodnes promítají do výuky ve všech vzdělávacích stupních ve Spojených státech. I z tohoto důvodu je velmi často citován v souvislosti s výukou design-build projektů zejména v anglosaské odbornéliteratuře.

\section{Seznam použité literatury}

ANDERSON, Jane a Colin PRIEST. 2014. Developing an Inclusive Definition, Typological Analysis and Online Resource for Live Projects. In: Harriet HARRISS a Lynnette WIDDER, ed. Architecture Live Projects: Pedagogy into Practice. 1. vyd. New York: Routledge, s. 9-17. ISBN 978-0415733526.

CARPENTER, William J. 2004. Design and Construction in Architectural Education 1963-2003 [online]. Disertační práce. University of Central England in Birmingham, Faculty of the Build Environment, Birmingham School of Architecture. Dostupné z: http://ethos.bl.uk/OrderDetails.do?did=2\&uin=uk.bl.ethos.409152

GRAVE, Gabriele D. a Rainer K. WICK. 2001 Teaching at the Bauhaus. 1. vyd. Ostfildern-Ruit: Hatje Cantz Publishers. ISBN 978-3775708012.

FATTINGER, Peter. 2014. What To Build - On the Thematic Diversity of University-Based Design-Build Assignments and Their Different Impacts on the Learning 
Outcome. In: Ted CAVANAGH, Ursula HARTIG a Sergio PALLERONI, ed. Working Out: Thinking While Building. 1. vyd. Washington: ACSA Press, s. 165-172. ISBN 978-0-935502-94-7.

GREGORY, Alexis. 2014. Design-Build as Collaboration: Hands-on Construction to Facilitate Communication and Dedication. In: Ted CAVANAGH, Ursula HARTIG a Sergio PALLERONI, ed. Working Out: Thinking While Building. 1. vyd. Washington: ACSA Press, s. 505-513. ISBN 978-0-935502-94-7.

HAYES, Richard W. 2007. The Yale Building Project: The First 40 Years. 1. vyd. New Haven: Yale University Pres. 978-0-300-12316-6.

KOSTOF, Spiro, ed. 1977. The architect : chapters in the history of the profession. New York: Oxford University Press. ISBN 0-520-22604-6.

KRAUS, Chad, ed. 2017. Designbuild Education. 1st vyd. New York: Routledge. ISBN 978-1138956308.

MORROW, Ruth. 2014. Live Project love: building a framework for Live Projects. In: Harriet HARRISS a Lynnette WIDDER, ed. Architecture Live Projects: Pedagogy into Practice. 1. vyd. New York: Routledge, s. xviii-xxiii. ISBN 978-0415733526.

PALLASMAA, Juhani. 2012. Myslící ruka: existenciální a ztělesněná moudrost v architektuře. Zlín: Archa. ISBN 978-80-87545-09-6.

ŠVEC, Vlastimil et al. 2016. Studenti učitelství mezi tacitními a explicitními znalostmi. 1. vyd. Brno: Masarykova univerzita. ISBN 978-80-210-8428-5.

TSCHUMI, Bernard. 1995. One, Two, Three: Jump. In: Martin PEARCE a Maggie TOY, ed. Educating Architects. 1. vyd. London: Academy Editions, s. 24-25. ISBN 978-1854903914.

The School of Architecture at Taliesin [online]. The School of Architecture at Taliesin [cit. 2018-08-30]. Dostupné z: http://taliesin.edu/app/uploads/Taliesin-Official-BrochureSM.pdf

VERDERBER, Stephen. 2014. Territories of Educational Design-Build: Toward an Evidence-Based Discourse. In: Ted CAVANAGH, Ursula HARTIG a Sergio PALLERONI, ed. Working Out: Thinking While Building. 1. vyd. Washington: ACSA Press, s. 174-185. ISBN 978-0-935502-94-7. 